\begin{abstract}
This article considers the responses of women, many of whom describe themselves as housewives, in the 1949 Mass Observation Television Directive, in order to interrogate some of the broader assumptions around television's relationship with 'the housewife' as key to its success. Against the backcloth of social histories revising ideas about gender, modernity and suburbia in the post-war period, this article considers some of the ways in which initial reluctance towards television was recorded and negotiated. It presents three themes around tensions between home and leisure, the domestication of entertainment and 'going out', and the appreciation of particular genre, which suggest that the adoption of television as mass entertainment by women might not have been as smooth a process as we have come to understand.
\end{abstract}

Keywords: Television, housewives, gender, mass-observation, home, post-war period. 


\section{Television - The Housewife's Choice? The 1949 Mass Observation Television Directive, Reluctance and Revision.}

\section{Introduction}

It is widely accepted that the adoption of television was successfully achieved partly through an address to women as custodians of the home in the 1950s. The housewife's role in the domestication of television has been reconstructed in television history through consulting written broadcasting and magazine archives. She was addressed as the ideal consumer, figured as part of the broader social shifts of suburbanisation, modernisation and consumerism during post-war reconstruction in the United States and Britain (Oswell, 2002, Spigel, 1992, Thumim, 2004). The more contemporary popular and academic association of women with soap opera seals an understanding of the relationship between television form, its commercial 'mass' appeal and the feminisation of the medium. But how might we hear from women as audience members in those early days of television's adoption? Importantly, how can we insert their voices as part of that now accepted narrative of women as pioneering audiences of television? This article uses the 1949 Mass Observation Television Survey and the accompanying Directive responses, which are important because they predate the widespread take-up of television, capturing a moment when many are just contemplating the idea of television as something they have glimpsed in others' houses, at exhibitions or in shop windows. It takes the voices of women as they have been collected in the Mass Observation archive (hereafter MO) and presents three dominant themes around i.) home and leisure, ii) 'going out', and iii.) the appreciation of particular genre, which add important qualifications to any notion of the easy acceptance of television by women during a period of instability when home and domestic life were being transformed by modernity.

\section{Television and the housewife}

Social histories of television record a narrative through which the figure of the housewife emerges as central to television's widespread adoption in the 1950s in Britain and America. This continued radio broadcasting's success in addressing women, targeting them in the daytime as at the centre of the household, and through genres and formats that were carried over from radio to television (Hilmes, 1997). Maggie Andrews (2012) describes the way across both radio and television the airwaves were 'domesticated' as content addressing women as the experts of household management thrived, mirroring broadcasting's site of consumption. Lynn Spigel's (1992) account of the growth of commercial television in the States outlines the ways in which women's magazines and broadcast publications were replete with articles on the benefits of television, on its usefulness to family life and how it could be styled into the modern suburban home. Here the post-war emphasis upon suburban dwelling, women's apparent return to the home after the war, and the simultaneous need for national communications, all combine to produce conditions ripe for the entry of television. Learning from radio, television set manufacturers and broadcasters realised they should convince the housewife of the joy of television as she held such influence over domestic purchases, despite men's interest in the technical aspects of set-building. According to Thumim (2004) in the UK, the female audience was central to television's adoption in two respects: in establishing television viewing as part of domestic routine, and as primary consumers in the burgeoning domestic marketplace. Helen Wheatley (forthcoming) describes how television was marketed to women in the Ideal Home Exhibition in Britain as part of the emerging narrative of home as a site of joy and leisure, soon to be replete with a host of labour-saving devices. In the US the television thus became a symbol for modern living 
whereby the set began to displace the hearth as the space for the modern family to come together thus central to the narrative of nation-building in the aftermath of war (Ticchi, 1992). Whilst David Oswell sums up the British context, where, 'Television was to signify an important boundary marker between the traditional and modern home. Television was seen to articulate a different sense of domestic life, a new science of modern living'. $(2002,89)$

Because the home was an important site of family leisure during post-war reconstruction it has often been accompanied by a notion of a seamless return to traditional gender roles and the figure of the 'happy housewife'. But as Lynn Spigel (1992) has already signalled, the home was a contradictory site for women and the suburban home had to accommodate women's ambivalent relationship to it as a site of leisure and of labour. Television's appeal to women therefore also had to bridge this tension and Spigel (1992) describes such interventions as the 'TV Stove', marketed by the Western-Holly Company in 1952, as emblematic of the need to integrate the housewife into the family circle, whilst still ensuring her productivity. In the British context, Janet Thumim (2004) describes a raft of television programmes in the late 1940s and early 1950s which had a conscious address to women as housewives (e.g. For the Housewife, BBC 1948 or About the Home, BBC 1951-8) which directly tried to fit in with, rather than disrupt, the housewife's working day. This suggests a number of points which this article begins to address: Firstly, there were deliberate efforts on both sides of the Atlantic to convince the housewife of the value of television, secondly, there must have been national distinctions in this process given the different institutional, commercial and cultural contexts, and finally, and, although the BBC conducted its own audience research in the $1950 \mathrm{~s}^{\mathrm{i}}$, the growing literature on the lives of housewives during the period has not yet been discussed in relation to the emergent television audience.

The image of the 'happy housewife' at peace with her television was a powerful marketing strategy visible in magazines and in some programming, and it is also part of a figurative and often mythologised image of the post-war housewife which has been re-assessed by feminist historians. They offer a picture of the re-negotiation of conflicting roles for women during the post-war period, which might help us to locate any sense of the housewife television audience of the time. Immediate post-war conditions were harsh during a period of austerity with housing shortages, falling population rates and increasing divorce rates (Giles, 2004). Between 1931 and 1951 the proportion of women in employment rose from $26 \%$ to $43 \%$. (Bourke, cited in Langhamer, 2005) Both wars saw a period where women's roles were considered significant 'on the home front' and in the Second World War a host of 'mobile' women were conscripted into work which contributed to their increased employment numbers (as well as inferior pay and conditions) after the war. (Summerfield, 1984) The decline in domestic service and new opportunities in the rising consumer service industries also contributed to the increase in female employment. Therefore any neat picture of 'the happy housewife' is complicated by the fact that she often also worked outside of the home, or would have probably worked before having children, depending upon her class location.

The focus on the home as a site of post-war reconstruction also inevitably gave some considerable responsibility to women because issues like rationing, domestic service and re-building home life were central to public debate. Rationing, still in place until 1953, was a source of much distress for the housewife struggling to feed and clothe her family, and in the 1951 UK election the Conservative's address to the housewife, with a policy to bring an end to rationing, was largely credited for their victory (Zwenigar-Bargileowska, 1994). The housewife therefore had a fundamental role directly connected to the economy and to citizenship through her power as consumer and her responsibility as family/nation builder, rather than being totally marginalised by her attachment to home. ZweinigerBargielowska's (2001) offers us a more complex subject formation of the 'citizen-housewife' whilst 
Elisabeth Wilson (1980) suggests that any image of the passive home-loving woman of the 1950s was actually an ideological construct created by a host of different official sources.

This more complex picture of women's position is also reflected in research into historical representations of the housewife of the post-war period in Britain. Melanie Bell (2010) has challenged the idea that the happy 1950s housewife dominated post-war British cinema by detailing many film observations of social unease containing proto-feminist ideals. Kristin Skoog (2009) describes the BBC's address to the housewife on Woman's Hour (BBC Radio 4 1946-present) as recognising women's roles in the process of modernisation and in bridging the public/private divide. Similarly the role of radio in establishing the formats for television sees the development of a daytime schedule through which a programme like Mrs Dales Diary (1848-1969), especially in its earlier form, contributed to a more complex and woman-centred picture of post-war reconstruction (Skoog, 2013). In television history Joy Leman (1987) and Janet Thumim (2004) have drawn our attention to the role of the BBC's women's programming unit between 1953 and 1964 and Mary Irwin (2011) discusses the work of its Head, Doreen Stephens (Irwin, 2011) in offering programmes that captured some of the tensions for women at home and addressed the rising number of working women. Rachel Moseley (2008) analyses the work of Marguerite Patten in early British television cookery programmes which contained a proto-feminist address, whilst Gillian Murray (2014) discusses how ATV regional television news also generated a space for women to speak as housewife-citizens. All of this proffers a re-imagining of the relations between women, housewives and the turn to domesticity into which television was received, but how might we reach the housewife/woman as the ideal audience member for television?

\section{Television, women and the Mass-Observation archives}

Tim O'Sullivan (2007) and Henrik Ornebring (2007) both point us to the holdings of the Mass Observation Archives in Sussex as sources in order to capture some sense of the early television audience. The original MO movement initiated by Charles Madge, Humphrey Jennings ${ }^{\mathrm{ii}}$ and Tom Harrisson drew together a large of panel of observers, diarists and commentators to document a 'science of ourselves' in order to detail 'ordinary life' between 1937 and 1949, continuing later as market research. Its social research has been described as more of a left-ish quasi-political social movement, a product of their concerns over what they saw as the press's failure to represent 'the social consciousness of the time' (Summerfield, 1985: 440). Charles Madge assembled a 'panel' of respondents to whom they issued regular, sometimes, monthly directives on different topics of the day. (2,847 respondents replied to at least one directive). Separately, around 200 were asked to keep regular diaries. Whilst a report on cinema-going has been published (Richards and Sheridan eds. 1987) it is only more recently that the archive is being made useful to our understanding of the adoption and domestication of television (Moran 2013, O'Sullivan 2007 and 2012b, Ornebring, 2007).

Henrik Ornebring's (2007) work on the MO records of the 1953 Coronation produces some important qualifications to received assumptions about the domestication of television, recording patterns of resistance and negotiation. Tim O'Sullivan (2012b) charts how, partly using the 1949 MO survey, the arrival of television was considered both modern miracle and dangerous distraction, replacing other more useful forms of occupation. The 1949 Television survey report and the associated Directive are useful because they capture a period where television is still in its infancy, before the establishment of a widespread viewing public. Douglas Gomery (2001) writing about the US, argues that there is a need to distinguish between television's fast-paced adoption, where there is a good deal of writing 
about 'the 1950s', and an earlier period in the late 1940s when television was picked up again postwar which is also an important observation for the British context.

The BBC public television service in Britain began in 1937 but only 20,000 sets were sold before the war. The service was restarted after the war, after much discussion during a time of austerity in 1946, and enjoyed a period of monopoly until the arrival of commercial television with ITV in 1955 (O’Sullivan, 2003). MO conducted their survey in February 1949 with 684 people of whom only 2\% actually owned a television set. $37 \%$ had never seen television, $40 \%$ had seen it more than once, $14 \%$ had seen it only once and 7\% had seen it, but not since the war, and the results were published as a bulletin. ${ }^{\text {iii }}$ Whilst MO conducted numerous surveys for various organisations and bodies, there is no information about this particular survey or whether it was commissioned for a particular audience, in accounts of the MO (Hinton, 2013). However, to supplement the data produced from the survey MO also asked its panellists the same survey questions for which the original data has survived ${ }^{\text {iv }}$. This paper is based upon the panellist responses to these survey questions: 'a.) How do you feel about having television in your home? (Please answer this question whether or not you live in a television area). Please also state, a) whether you have a television in your home or b) whether you have ever seen television transmitted. b) If you had a television how do you think it would affect your home leisure pursuits (e.g. reading, listening to the wireless, playing the gramophone etc.)'

If the MO archives are a useful site for retrieving knowledge about the historical television audience, it is important to know something of the panellists. It is generally understood that the majority of the respondents were left-leaning and lower middle-class, because they would have had the time and inclination to commit to the project. In fact the class profile of the body of the participants proved a little troublesome for Harrisson and Madge as it did not reflect as large a working-class population and they had often liked to claim (Hinton, 2013). Many respondents had won scholarships to elementary school but few had gone to university and typical occupations listed were clerks and school teachers (Summerfield, 1985). Interestingly, the majority of women respondents classified themselves as housewives:

The invitation to send in their most intimate thoughts and feelings and what they knew of those and of others around them must have given them a sense of being listened to which was itself counter to their powerlessness. This may have been particularly important to women who, in spite of having won the vote, were still largely deprived of a 'voice' in traditional party politics and trade unions organisations between the wars. In addition gossip, as well and news, home life as well as work, sex as well as politics, were considered important, an acknowledgement that the 'personal' is 'political.' (Summerfield, 1985, 442)

In 1949 the MO had a better rate of response to its directives than at any other time in its history (Hinton, 2013). There are 732 responses to this 1949 Television Directive in the MO files, of those 187 can be definitely identified as women, and yet accounts suggests that after the war 50 percent of panellists were women of which around 47 percent occupied the large category of the housewife (Hinton 2013).

There are some methodological difficulties in taking this archival data as evidence of the housewife audience in 1949, since it obviously represents a relatively small sample, and the directive responses do not reveal a great deal about the identities of the respondents (only name, age, marital status, occupation and index number). The large category of 'housewife' also hides the class profile of the women respondents. What we have in the archives is a set of some typed and some handwritten responses, some difficult to read, all without much information about their authors, despite them being 
organised by gender. Summerfield (1985) also notes that there may have been few mothers amongst the respondents because of the time associated with the commitment to the project, which is a shame given television's address to women as mothers and the history of children's television in Britain (Oswell, 2002). Nevertheless, despite these limitations, the MO archives still provide a site with which we can begin to retrieve the voices of housewives as they first encountered the new medium of television, a technology that would become so tightly bound to ideas around the suburban family ideal of the post-war era. It offers up important narratives which might suggest we begin to revisit our ideas about television's easy acceptance as a mass medium in relation to the home, the negotiation of space and place and the gendering of taste, as the following discussion shows.

\section{Gender and time for television in the home}

The 1949 survey was conducted during a period when television reception was limited to the London area around Alexandra Palace and when only 3 in every 100 homes in that area had a television, just before the launch of the Sutton Coldfield transmitter which improved its geographical reach. At this point the survey report recorded a good degree of reluctance as well as enthusiasm for the new technology and $37 \%$ of those surveyed had actually never even seen television. Given the changing pace of the technology, $11 \%$ said they would like to own one at some point, $48 \%$ would like to have one, whilst $33 \%$ did not want one at all. One of the dominant concerns of the time was around the potential distraction from other leisure activities and the second question was 'If you had a television set how do you think it would affect your home leisure pursuits?' Most suggested that the biggest impact would be on radio listening, with 2 in 5 assuming that it will have an effect on reading, whilst two thirds think there will be an impact upon cinema-going. Whilst these impressions may have been largely borne out, the survey numbers tell us little of the gender negotiations around that simple phrase 'home leisure pursuits' which needs contextualising in relation to the struggles over the social meanings and tensions over 'home' during that period.

The meanings of home collected by MO in 1942 reveal a differentiated picture of home for women and men (Langhamer, 2005). When asked 'what does home mean for you' more men than women described home as a 'pivot of their life', whilst women were concerned with the way in which a home needs to be run: 'It matters more to the ordinary woman that her home should be aesthetically furnished, that it should be light and be practical to run.' ${ }^{\mathrm{v}}$ These gendered distinctions in the home as a site of leisure and as a site of work begin to be revealed in some of the concerns over television's potential as a distraction from domestic duties. O'Sullivan (2012b) cites one quote used in the MO Television survey report:

Apart from the wasted evening's prospect, what housewife (middle or any other class) would have the time to sit down and watch television in the morning and the afternoon? With the radio women can work; and hum with the 'Housewives Choice'. With television they would not be able to watch the screen and make the pastry. What mysteries would be brought forth from the oven at dinner time, due to the irresistible distractions of the cathode tube' (24 year old Clerk, MO Bulletin series number 30, August 1949).

One cannot tell from the report whether this quote is from a male or female but it echoes Spigel's (1992) accounts of the social fears around television in the US as disruptive for women working at the centre of the home. Looking beyond the survey report to some of the February 1949 Directive responses, we can see the anxieties of housewives as they consider how television might intervene in their daily productivity. 
I have no television set. I am not very interested in having a television set at present. I feel a lot of spare time is needed for 'viewing' and at the moment my very limited spare time is very well catered for by the wireless, books and handworks [....] the worst of television, from a housewife's point of view is it requires a darkened room, so that knitting or mending is out of the question, whereas to mend whilst listening to the wireless makes a tedious job less irksome! (DR no 1485, Housewife, aged 28)

Not at all keen about having television [...] Have not sufficient leisure time at home with present occupations and interests such as reading, mending, listening to the gramophone, talking to friend etc., cooking etc. etc. (DR no 9165, Housewife, aged 42).

Across the responses there is thus a good deal of reluctance towards television from housewives which is inextricably bound up with pressures upon time and their list of chores. This is added to the fact that the earliest affordable sets also had small screens and there was an assumption that they needed darkened rooms preventing work that requires careful concentration from the eyes.

I am not at all keen to have a television in my own home, I think it would be very little used and not justify the expense at all... the wireless does at least rest one's eyes and so the mending etc. can be tackled while programmes are enjoyed (DR no 0210, Married, housewife-mother, aged 30)

This is somewhat different to the responses from men about home-leisure pursuits where their concerns are more repeatedly about the displacement of reading:

It would undoubtedly interfere with other pursuits. As I do not arrive home until after 6.30 there is little enough time to get on with anything after an evening meal, a wash and a change of clothes, and my reading is, even now, sadly neglected. (DR 0156, male, no age or occupation supplied)

Whilst for some men this warns against television, others contemplate how it might take its place amongst a range of other leisure pursuits:

I do not think it would affect my leisure pursuits after the initial phase of novelty had passed away. Once the phenomenon had become a familiar occurrence it would tend to take the same place as compared with radio and the cinema, or radio as compared with book reading.

If I was in the middle of an interesting book, the cinema would not see me. If "Hamlet" was showing locally "? Binding" would have to wait. Likewise television would have to be weighed up with my other pleasures and take its appropriate place. (DR 4067, male, Clerk Public Health Department, age 22 1/2).

It is possible to read this difference as straight-forwardly about the pressures of time and the confines of the home as an oppressive site of labour for women, in keeping with second-wave feminism (e.g. Friedan, 1964, Oakley, 1975). But it is also important to contextualise these responses in relation to the revised understandings of the housewife of the post-war period described above.

Unlike the men's responses to this question, for the housewives there is no easy distinction between what we might see as chores and leisure pursuits: 
There are only a certain number of leisure hours and I am afraid knitting or sewing would suffer. One can listen to the wireless and knit and sew at the same time, but I could not do these whilst watching the television screen. (DR 1850, housewife, aged 47)

I do most of my ironing and mending in the evening, and would find it hard to watch television and iron or mend. But I doubt if it would worry me much because the programmes don't last the whole evening as a rule, I believe and I'd have to knit while I watched and leave the mending till the programme was over. (DR 1948, married housewife, aged 34).

These were common responses where acts like knitting and sewing are presented more as part of the evening's leisure rather than daytime labour: activities which are simultaneously work and leisure. There is evidence in fact that knitting became a common pursuit for women whilst watching television in the 1950s, which Claire Langhamer (2000) suggests is because it remains attached to a work ethic.

In these expressions of reluctance towards television, the women are articulating an anxiety about television as a potentially disruptive force. Across the narratives the idea that television might block rather than assist family communication is of equal concern for both men and women. But the intensity with which the housewives discuss television's potential intervention in the processes of 'making' and 'keeping' home is apparent and it might be related to their investment in 'home' of the period. For these lower middle-class women the return to the home and the embrace of the suburbs can be understood as presenting a site of security and safety after the war and during a period of housing shortages. Lower middle-class women and working-class women may have been until recently more likely to be employed in domestic service, but this practice was increasingly in decline and by 1951 only $11 \%$ of women in the labour market were classed as 'indoor domestic' a drop of $50 \%$ over twenty years (Jackson, 1991, cited in Giles, 2004). Judy Giles (2004) persuasively argues how the changing nature of domestic service and the rise of the suburbs (too often ignored in accounts of modernity ${ }^{\mathrm{vi}}$ ) made the label of the 'housewife' a relatively egalitarian one since it now pertained to both middle and working-class woman. It was therefore adopted by many women as a source of pride: 'When working class women demanded the opportunities to housekeep their own home in the suburbs they were asserting their right to that comfort and ease that for too long had been denied them'.

(Giles, 2004, 95)

For many housewives therefore, television may not have been straight-forwardly adopted as that symbol of modernity related to their consumer passions, at least not during these early years of television in 1949. For some, television was then antithetical to their newly important modern roles as 'housewives' and the investment of their time into the 'home' in the immediate post-war period.

\section{Brokering the physical private/public divide: 'staying in' or 'going out'}

Whilst broadcasting has directly attempted to fit into domestic rhythms, much has also been made of the exciting possibilities of television to transcend home. (Boddy, 2004) In accounts of broadcasting's role in brokering the conditions of modernity this ability to re-configure public/private spheres has been central to some of the re-negotiation of gender relations (see Meyrowitz, 1986 and Moores, 1988). But here I want to present some of the rather pragmatic ways in which the women in the survey talked about the idea of television in terms of public/private space. They speak of a tension over 'going out' or 'staying in' and its relationship to marital relationships at a moment where homeentertainment is about to become a significant feature of suburban living. 
The potential of the medium to transport us to distant places is part of the 'dreams' for the modern medium, the promise of the technology and ideas about the 'future' and escape (O'Sullivan, 2012b). The 1949 survey report gives us one such example:

We have had a working television set for nearly two years now and have derived great pleasure from it. The children love it too, and they've learned a lot even at their immature ages of three and four. How many children have been to the Antarctic and seen the seal and penguins, or viewed the antics of a skiing school in Switzerland, or laughed with real abandon at Laurel and Hardy's tumbles and horseplay. (29 year old housewife, MO Bulletin series no 30)

Here, in the report, the transportative potential of television is attributed to opening the minds of children, potentially as they are invested in as 'the future'. But looking closer at the Directive responses, the ability of television to mediate place, was also related to more modest requirements of television bringing entertainment into the living room.

Although I do not live in a television area and so have no television set, nor have ever seen television transmitted, I should like a television set in my own home. As one gets older one feels less inclined to go out to amusements and a television set would bring almost any kind of entertainment to one's own fireside. (DR 1850, married housewife, aged 47, February 1949)

Some of these wishes pertain to the democratising effect of television - here of getting to see the great ballet dancers that this (lower middle class?) housewife would not otherwise have been able to see:

I look forward with great eagerness to the time when we have television in our own home. On the Radio Times this week there is a picture of Moira Shearer and Alexis Rassine and I felt most envious when I read that they are to dance together on television on Saturday. I don't suppose I shall have the chance to see 'the great ones' except through the medium of television and so the quicker it gets here the better. (DR 4338, married housewife, aged 28)

The relationship of television to the public world therefore is not only one of far-flung places, but also one in which there is appreciation of television's ability to mediate other public spaces: the theatre, the cinema, and as we shall discuss later, the sporting arena. Of course, not all of these spaces were evenly populated by women or by women of different classes.

Against accounts of the delights of bringing the mediated public world in to the home, is also reluctance towards television supplanting public entertainment space.

I cannot imagine any way in which television would improve the existing facilities for entertainment. If I want to go to a play or film I'd much prefer to go to the theatre or the cinema. (DR 1840, School teacher)

For some of the women in the survey there is concern that television might actually further secure them within the physical space of the home:

Kenneth has bought a television set, but I would not refuse an engagement out in order to 'stay in'. (DR 016, teacher-housewife, aged 58)

Just now I feel that I want something that will take me out of doors as often as possible, for when at home there is so much sewing and writing to do (DR 039 teacher, aged 52) 
I do not think I should feel like having a television set in my home as it would tend to keep me from going out to see a show and as I am a housewife I do like to get away, as much as I love my home, to reap the full benefit of an evening out. (DR 4637, housewife, no age given)

There was a very practical concern here for some women about the very immediate impact of more home-centred entertainment.

Accounts of suburbia in the UK and the US describe the rise of home-centred entertainment as key to a new emergent culture (Giles, 2004, Silverstone 1997, Spigel, 2001). For women, this potentially had added benefits of keeping children in the home for security, and men at home and out of the pub. Even in Young and Wilmott's (1957) study of 'Greenleigh', in their largely negative assessment of the new estates and suburban living conducted in the mid-1950s, they attribute television a role in the rise of 'companionate marriage':

We can see that husbands not only do more to aid their wives in emergencies; they also spend less on themselves and more on their families. When they watch television instead of drinking beer in the pub, and weed the garden instead of going to a football match, the husbands of Greenleigh have taken a stage further the partnership mentioned in an earlier chapter [...] The 'home' and the family of marriage becomes the focus of man's life as of his wife's. (Young and Wilmott 1957, 145 cited in Langhamer, 2005)

There are examples from the Directive in 1949 where women anticipated television as contributing to good marital relationships:

I really don't think that it would affect us much as we should probably listen to the wireless for our favourite programmes just the same though if we had a television too. We have no gramophone so it wouldn't affect us. But if we had all these things, I feel that my husband and I would turn to whichever we felt in the mood for. We both love to sit in the firelight sometimes and of course would feel at home with television then. (DR 4218, married housewife, aged 24)

Judy Giles (1997) describes the way in which after the First World War ideas about companionship, pleasurable sex and birth control circulated more widely; however, other feminist interventions have argued that the idea of the companionable marriage was not an even experience, particularly for working-class women (e.g. Finch and Sommerville, 1991). As already discussed we do not know the precise class location of the women respondents of MO, but as we might expect there is a great deal of ambiguity around this issue. As one respondent, cited above, continues:

(2) Generally speaking I am certain a television set in the home would tend to make one lazy whereas if you go out to a show it means extra sprucing up (a joy to a woman who has been busy around the house most of the day). Expect hubby would prefer sitting back in his favourite armchair and have the goods come to him though. (DR 4637, housewife, no age given, my emphasis)

Keeping the husband at home and away from the pub is not straight-forwardly appreciated as part of companionate marriage, it is also registered as an anxiety about wanting to get out of the home, with that other delight of the 'extra sprucing up' of feminine identity. Whilst television might indeed contribute to the husband's increasing sense of the home as leisure, we can also detect a certain 
degree of resentment towards that here. The brokering of physical public/private space therefore is also tied to the series of tensions around the home as leisure and labour and echoes Langhamer's (2005) broader discussion of the meanings of the post-war home where 'revision and negotiation, rather than acceptance and acquiescence are perhaps the most helpful way of understanding gender relations in this period.' $(2005,356)$

\section{A preference for drama and an appreciation of sport}

There is a common held assumption, which has been confirmed by contemporary audience research about the gendering of taste distinctions, that women have a preference for drama whilst men have a preference for factual programmes. Of course the gendered popularity of soap opera began on early commercial radio in the US (Douglas, 2004) and was transferred to the television viewer through soap operas which tuned into her working day (Modleski, 1983). But soap opera came a little later in Britain; Michele Hilmes (2007) describes the BBC's initial resistance to addressing housewives and its snobbery towards American soap opera. It was only the need to speak to women directly as a form of propaganda in the Second World War that initiated the first British soap on radio, Front Line Family in 1941. Of course later in the 1980s feminist television studies itself also cemented the relationship between the housewife and the soap opera (Brunsdon, 2000), but is that what she wanted of television at its inception?

When women in the survey spoke about available genres, they were most keen on seeing plays on television, which is perhaps connected to ideas about bringing the theatre into the living room.

I imagine that if I had a television set I should want to view all plays and that would affect mending and sewing (DR 202, married, housewife, aged 62).

I would infinitely prefer to see as well as hear. Also television would bring an added interest to plays, as all plays are not suitable for just hearing alone. (DR 1850, housewife, married, aged 47)

But there is also a strong theme whereby plays are associated with high culture.

I live in a television district but I would not have a television as a gift...I would only care for television for plays. (DR 062, single, retired trained nurse)

I enjoy 'Café Continental' vii, some ballet and straight plays (not comedies which do not seem humorous to me) (DR 016, teacher-housewife, aged 58)

We haven't got a television set, though we are JUST within the London area...I would like to have a television set: the plays seem to cater for a more advanced audience (DR 1848, married, housewife, aged 34)

The nurse cited above is also extremely scathing of variety and there are plenty of examples of women critiquing genres in terms of cultural markers of taste.

However, there are also a surprising number of references by women to the appreciation of sport on television. In Douglas Gomery's (2001) attempt to find US television's pioneering audience he describes the centrality of sportscasting to the establishment of early viewership, where the screening of the world base-ball series or key heavy-weight boxing fights provided the impetus for set purchases. He suggests that this was heavily gendered, where television meant savings for men on sports tickets and for women on theatre tickets. However, in Britain, Tim O'Sullivan (2012a) has 
suggested that the televising of the 1948 London Olympic Games was extremely important to the establishment of television. This might begin to explain why in the MO responses to the 1949 directive, a number of women list sports as a reason they would like to own a television set. This is asserted by a number of housewives as well as single women:

The Saturday afternoon sports programmes appeal to me, but I usually have to go shopping from 3 to 4 or 5 pm and miss a lot. (DR 016, teacher-housewife, aged 58).

Television is a great saving of money. I could not afford seats at Wimbledon to watch tennis so I watch the matches on my set; the same applies to racing, in comfort I will watch the Ascot races, and also see the dresses of the women walking in the paddock. (DR653, single, aged 42)

I have not a television set but know several people who have. Have certainly seen television transmissions and think it is wonderful, especially for actualities and sporting events. (DR 1607, female, single Clerk, aged 42).

I feel the interest value of having television in my home would be tremendous. I should love to see the royal processions and any other pieces of pageantry. I should like to see Test Matches, the Grand National and the Derby, Davis Cup matches etc. (DR 1246, single, aged 27.)

In these responses, sport is appreciated for its spectacle, for its outside broadcasts that are also connected to pageantry and royal occasions. These events all became part of British television's broadcast calendar (Scannell and Cardiff, 1991) and whilst the royal occasions might seem to be more centrally part of an address to the female consumer/citizen, sport has rarely been interrogated as such. In television studies, an assumption supported by more contemporary audience research (Morley, 1986 and Lull, 1990), has tended to reinforce an understanding that sports, as part of the factual world is more appreciated by men, whilst fiction, again reinforced by research into the soap opera, is more appreciated by women.

However, Hazel Collie's (2014) research into different generations of women's memories of television showed that sports programming emerged as a fond memory for women watching with family relatives, often fathers, and she also describes how sporting figures provided televised objects of desire. In our survey of British television's afternoon schedules, a time of day generally thought to be targeted to women, we saw that sport took up around a third of scheduling space in the mid-1960s and early 1970s (Moseley, Wheatley and Wood, 2014). Barbara O'Connor and Raymond Boyle (1993) have suggestively argued that televised sport and soap opera are not so radically different in that they invoke similar structures of feeling in their audiences. Here, in the responses to the MO survey we can clearly see that at the outset there was no normative assumption that televised sport was necessarily 'for' men and that the British sporting calendar which includes, cricket, tennis and racing were seen to be of national interest for women as well. This suggests that the historical relationship of women to televised sport is a story that is not yet being fully told.

\section{Conclusion}

These responses to the 1949 Television Survey and Directive in the Mass Observation archives provide one way of inviting women's voices to contribute to our historical understanding of their role in the take-up of television as a technology. I deliberately chose dominant themes that trouble some of our assumptions about the relationship between women and television to reveal some of the 
reluctance and anxiety towards the new medium and to broaden our understanding of television's process of becoming a domestic and gendered technology.

Echoing Gomery's (2001) discussion of the pioneering audience of the US, it is possible to periodise television's early inception in post-war Britain, rather than to subsume it within the dominant narratives about 'the 1950s' where television took its place in the consumer boom across both sides of the Atlantic. In these instances we can hear from the women's words clear records of their negotiation of the relationship to home as a site of labour, leisure and also pride. It has also shown how ideas about television as a site for re-negotiating the private/public divide are centred around practical considerations of women 'getting out' and men 'staying in' suggestive of how gender relations might play out post war in the rise of suburban home-centred entertainment. Finally, whilst the soap opera has a privileged status as integral to the appeal of television for the housewife, this research has shown that initially many women sought drama through the 'higher' forms of the play and appreciated the assumed masculine spectacle of sport. It is therefore important that any understanding of television's early inception must be sensitive to the broader social histories of the time, many of which have undermined any unified notion of 'the housewife' amongst the disruptive forces of modernity in the post-war period. Therefore television may not have been easily accepted by women as a key symbol of the modern home or as the ideal site for mass entertainment as it might be assumed, and television was not always the housewife's choice at all. 
References

Andrews, Maggie. 2012. Domesticating the Airwaves: Broadcasting, Domesticity and Femininity London, Continuum.

Bell, Melanie. 2010. Femininity in the Frame: Women and 1950s British Popular Cinema London and New York: IB Tauris.

Boddy, William. 2004. New Media and Popular Imagination: Launching Radio, Television and Digital Media in the United States Oxford, Oxford University Press.

Bourke, J .1994. Working Class Cultures in Britain 1890-1960 London, Routledge.

Brunsdon, Charlotte. 2000. The Feminist, the Housewife and the Soap Opera Oxford: Oxford University Press.

Collie, Hazel. 2014. Television for Women: Gender, Generation and Everyday Life. Unpublished PhD thesis, De Montfort University.

Douglas, Susan. 2004. Listening In: Radio and the American Imagination. Minneapolis, MN:

University of Minnesota Press.

Finch, Judy and Penny Sommerville . 1991. 'Social Reconstruction and the Emergence of Companionate Marriage, 1945-59’ In D Clark (ed.) Marriage, Domestic Life and Social Change: Writings for Jaqueline Borgoyne 1944-88 London.

Friedan, Betty. 1964. The Feminine Mystique Harmondsworth: Pelican.

Giles, Judy. 1997. A World of Their Own Making: A History of Myth and Ritual in Family Life Oxford University Press, Oxford.

Giles, Judy. 2004. The Parlour and Suburb: Domestic Identities, Class, Femininity and Modernity Oxford, Berg.

Gomery, Douglas. 2001. 'Finding TV's pioneering audience' Journal of Popular Film and Television 29 (3): 121-129.

Hilmes, Michelle. 1997. Radio Voices. Minnesota, University of Minnesota Press.

Hilmes, Michelle. 2007. 'Front Line Family: Women's Culture Comes to the BBC' Media, Culture and Society 29 (1): 5-29.

Irwin, Mary. 2011. 'What Women Want on Television: Doreen Stephens and BBC Programming for Women, 1953-1964' Westminster Papers in Communication, 3(3): 99-12.

Jackson, A. 1991. The Middle Classes 1900-1950 Nairn, Scotland: David St John Publisher.

Langhamer, Clair. 2005. 'The Meanings of Home in Postwar Britain' In Journal of Contemporary History 40 (2): 341-362.

Langhamer, Clair. 2000. Women's Leisure in England, 1920-1960 Manchester University Press, Manchester. 
Leman, Joy .1987. 'Programmes for Women' in 1950s British Television' in Baehr, H and Dyer, G,(eds.) Boxed In: Women and Television, London: Routledge and Kegan Paul, pp. 73-95

Lull, James. 1990. Inside Family Television London: Routledge.

Meyrowitz, Joshua. 1986. No Sense of Place: The Impact of Electronic Media on Social Behaviour Oxford: Oxford University Press.

Modelski, Tania. 1986. 'The Rhythms of Reception: daytime television and women's work' in E.A. Kaplan ed. Regarding Television, Los Angeles, American Film Institute.

Moores, Shaun. 1988. The Box on the Dresser: memories of early radio and everyday life' In Media, Culture and Society 10 (1) 23-40.

Morley, David. 1986. Family Television London: Routledge.

Moseley, Rachel. 2008. 'Marguerite Patten, Television Cookery and Postwar British Femininity' In Stacy Gillis and Joanne Hollows (eds.) Feminism, Domesticity and Popular Culture London: Routledge.

Moseley, Rachel, Helen Wheatley and Helen Wood. 2014, forthcoming. 'Television in Afternoon' special issue of Critical Studies in Television

Moran, Joe. 2013. Armchair Nation: An Intimate History of Britain in Front of the TV London: Profile Books.

Murray, Gillian. 2014, forthcoming. 'Regional news and the mid-twentieth century 'housewife': Exploring the legacy of afternoon television in Midlands news programmes in the 1950s and 1960s' In Rachel Moseley, Helen Wheatley and Helen Wood (eds.) special issue of Critical Studies in Television

Oakley, Ann. 1975. The Sociology of Housework London: Pantheon.

O'Connor, Barbara and Raymond Boyle. 1993. 'Dallas with Balls: Televized sport, soap opera and male and female pleasures' Leisure Studies, 12, 101-119.

Ornebring, Henrik, 2007. 'Writing the history of television audiences: The Coronation and the MassObservation Archive' in Helen Wheatley ed. Re-viewing Television History: Critical Issues in Television Historiography London and New York: IB Tauris.

O'Sullivan, Tim. 2003. 'Post-war Television in Britain: BBC and ITV' in Michelle Hilmes (ed.) The Television History Book London: BFI.

O'Sullivan, Tim. 2007. 'Researching the viewing culture: television and the home, 1946 - 1960' in Helen Wheatley (ed.) Re-viewing Television History: Critical Issues in Television Historiography London and New York: IB Tauris.

O'Sullivan, Tim. 2012a. 'Television and the Austerity Games: London 1948' in Hill, J., Moore, K and Wood, J. (eds.) Sport, History and Heritage: Studies in Public Representation Boydell and Brewer pp. $76-90$.

O'Sullivan, Tim. 2012b. 'Dreams and Displacements: The Domestication of British TV in the 1950s' paper presented to the CAMRI research seminar series, University of Westminster. 
Oswell, David (2002) Television, Childhood and the Home: A History of the making of child television audience in Britain Oxford:

Richards. J and Sheridan D. eds. 1987. Mass-Observation at the Movies, London: Routledge.

Scannell, Paddy and David Cardiff. 1991. A Social History of British Broadcasting Oxford: Wiley Blackwell.

Silverstone, Roger. ed.1997. Visions of Suburbia London: Routledge.

Skoog, Kristin . 2009. 'Focus on the Housewife: The BBC and the Post-war Woman 1945-1955.' In Networking Knowledge: Journal of the MeCCSA Post graduate network 2(1): online date accessed 19/5/14 http://ojs.meccsa.org.uk/index.php/netknow/article/viewFile/35/35

Skoog, Kristin. 2013. 'They're “Doped” by That Dale Diary': Women's Serial Drama, the BBC and British Post-War Change.' In Helen Thornham and Elke Weissman (eds.) Renewing Feminisms: Radical Narratives, Fantasies and Futures in Media Studies London: I.B.Tauris.

Spigel, Lynn. 1992. Make Room for TV: Television and the Family Ideal in Postwar America, Chicago, University of Chicago Press.

Spigel, Lynn. 2001. Welcome to the Dreamhouse: Popular media and postwar suburbs Durham and London: Duke University Press.

Summerfield, Penny. 1984. Women Workers in the Second World War: Production and Patriarchy in Conflict London, Routledge.

Summerfield, Penny. 1985. 'Mass Observation: Social Research or Social Movement' Journal of Contemporary History 20 (3): 439-452.

Thumim, Janet. 2004. Inventing Television Culture Oxford: Oxford University Press.

Ticchi, Cecelia. 1992. The Electronic Hearth: Creating an American Television Culture Oxford University Press: Oxford.

Wheatley, Helen. forthcoming. 'Television in the Ideal Home' In Moseley, R, Wheatley, H and Wood, H (eds.) Television for Women: New Directions, London, Routledge.

Wilson, Elisabeth. 1980. Only Halfway to Paradise; Women in Post war Britain 1945-1968 London: Tavistock.

Young, M. and P Willmott. 1957/1962. Family and Kinship in East London London: Penguin.

Zwenigar-Bargileowska, Ina. 1994. 'Rationing, Austerity and the Conservative party recovery after 1945' in Historical Journal 37 (1), 173-97.

Zwenigar-Barhileowski, Ina. 2001. 'Housewifery' In Ina Zweinigar-Bargielowski, ed, Women in Twentieth Century Britain Harlow: Pearson Education.

'For instance 'Timing and Frequency of Programmes for Women, Children and Infants' Feb 1950 9VR/50/94, 'An enquiry about afternoon television programmes' 2 Nov 1955 VR 55/516, BBC Written Archives, Caversham. 
ii Although James Hinton's more recent history of MO suggests that the role of Humphrey Jennings has been greatly

iii SxMOA/1/1/14/8/1 Mass Observation Bulletin New Series No 30 August 1949.

iv The 1949 February Directive states, 'our second question is already used in a national sample, and on which we are anxious to obtain comparative results. This has not been in anyway altered from the form in which it was asked by our full time investigators, to people in the street' SxMoA 1/3/118

${ }^{v}$ M-OA FR 1616, 11 cited in Langhamer, 2005.

vi Judy Giles (2004) critiques masculine dismissive attitudes towards suburbia such as those of George Orwell.

vii Moran (2013) describes the variety show Café Continental as an English mirage of gay Paree - an escape

from the seemingly unending burden of post war austerity. 